\title{
Yield and Juice Quality of Sugarcane As Influenced By Ethephon and Gibberellic Acid
}

\author{
Subhashisa Praharaj ${ }^{1 *}$, Dheer Singh ${ }^{1}$ and S.K. Guru ${ }^{2}$ \\ ${ }^{1}$ Department of Agronomy, ${ }^{2}$ Department of Plant Physiology, G.B. Pant University of \\ Agriculture and Technology, Pantnagar, Uttarakhand - 263 145, India \\ *Corresponding author
}

\begin{abstract}
A B S T R A C T
A field experiment was conducted during spring 2015-2016 at Govind Ballabh Pant University of Agriculture and Technology, Pantnagar (U.S. Nagar), Uttarakhand to see the

\begin{tabular}{|c|}
\hline Keywords \\
\hline $\begin{array}{l}\text { Sugarcane, } \\
\text { Ethephon, } \\
\text { Gibberellic acid, } \\
\text { Yield, Juice quality }\end{array}$ \\
\hline Article Info \\
\hline $\begin{array}{l}\text { Accepted: } \\
\text { 12 October } 2018 \\
\text { Available Online: } \\
\text { 10 November } 2018\end{array}$ \\
\hline
\end{tabular}
effect of sugarcane sett soaking with ethephon and foliar application of gibberellic acid. Soil of the experiment plot was silty clay loam having high organic carbon (1.04\%), high available phosphorus $(32.5 \mathrm{~kg} / \mathrm{ha})$, medium in available potassium $(256.2 \mathrm{~kg} / \mathrm{ha}) . \mathrm{pH}$ of the soil was 7.2. Ten treatments i.e. conventional planting $\left(\mathrm{T}_{1}\right)$, overnight soaking of setts in water $\left(\mathrm{T}_{2}\right)$, overnight soaking of setts in $50 \mathrm{ppm}$ ethephon $\left(\mathrm{T}_{3}\right)$, overnight soaking of setts in $100 \mathrm{ppm}$ ethephon $\left(\mathrm{T}_{4}\right), \mathrm{T}_{1}+$ foliar application of $\mathrm{GA}_{3} @ 35 \mathrm{ppm}$ at 90,120 and 150 DAP $\left(\mathrm{T}_{5}\right), \mathrm{T}_{2}+$ foliar application of $\mathrm{GA}_{3} @ 35 \mathrm{ppm}$ at 90, 120 and $150 \mathrm{DAP}\left(\mathrm{T}_{6}\right), \mathrm{T}_{3}+$ foliar application of $\mathrm{GA}_{3} @ 35 \mathrm{ppm}$ at 90,120 and 150 DAP $\left(\mathrm{T}_{7}\right), \mathrm{T}_{4}+$ foliar application of $\mathrm{GA}_{3} @ 35 \mathrm{ppm}$ at 90,120 and $150 \mathrm{DAP}\left(\mathrm{T}_{8}\right)$, soaking of setts for six hours in $50 \mathrm{ppm}$ ethephon $\left(T_{9}\right)$ and six hour soaking of setts in 100 ppm ethephon $\left(T_{10}\right)$ were laid down in a randomized block design. All the treatments were replicated 3 times. It was observed that sett soaking with $100 \mathrm{ppm}$ ethephon followed by foliar application of Gibberellic acid resulted highest yield. In addition to yield, the juice quality was also improved in terms of sucrose content (16.94\%), available sugar percentage (11.60\%) and commercial cane sugar yield $(76.27 \mathrm{t} / \mathrm{ha})$ in this treatment.
\end{abstract}

\section{Introduction}

Indian sugar industry contributes significantly to the economy of India and to the socioeconomic development of the rural population in the country.

Sugarcane (Saccharum officinarum L.) sustains second largest agro-industry i.e. sugar industry, next to textile industry. It has been estimated that by 2030 , India will require 520 million tonnes of sugarcane with average sugar recovery of 10.75 per cent.

The required productivity to achieve this target is 100-110 tonnes/ha as the area under sugarcane cultivation is expected to stabilize around 5.00 million hectares. Yield and recovery pattern of last few years shows that the target is a stiff one (Anonymous, 2011). 
The existing management practice that largely focuses on good varieties, good quality seed material, nutrient management and pest management has not been able to achieve desired high productivity. Constraints like poor and delayed sprouting, poor tillering, poor growth and low sugar recovery has a bearing in low cane yield and sugar production. PGRs like ethephon and gibberellic acid has immense potential to ameliorate these constraints and thus has been effective in improving productivity and sugar recovery in sugarcane (Li and Solomon, 2003; Jain et al., 2011; El Latieff and Bekheet, 2012). The tremendous potential of ethephon in increasing sett sprouting has been reported from many countries like India, Colombia and Hawaii. Biochemical study in ethephon treated setts reveals that, ethephon treatment increases acid invertase activity and ATPase activity that helps in better sprouting (Jain et al., 2011). Better sprouting holds the key for optimum plant stand and hence yield. Improvement in sprouting percent, tiller population and yield due to ethephon treatmen has been reported (Millhollon and Legendre 1995, Manoharan et al., 1992; Rao et al., 2005). Improvement in yield due to foliar application of Gibberellic acid has been reported by El-Lattief and Bekheet (2012).

Plant growth regulators have also been able to enhance juice quality of sugarcane. Most of the existing agro techniques have been unsuccessful in improving the juice quality of sugarcane and thus yields lower commercial cane sugar. Use of PGRs (ethephon and gibberellic acid) has been able to improve both the productivity as well as juice quality of sugarcane. Setts treated with ethephon, when planted have also been reported to improve tillering and sucrose accumulation in cane (Zhang et al., 2001). Foliar application of gibberellic acid has been found effective for improving productivity as well as juice quality. Bull (1964) reported that application of gibberellic acid increased stalk length, fresh weight and sugar content of sugarcane. Alexander (1968) also reported increase in yield and juice quality of sugarcane due to foliar application of Gibberellic acid.

In addition to PGRs some non-monetary techniques like sett soaking with water has also been found to improve productivity of sugarcane by improving sprouting and subsequent growth. There has been a strong influence of sett moisture on germination of sugarcane. Nodal water content of $72-74 \%$ has been found to be optimum for rapid and high germination (Verma and Sudama, 1965; Singh, 1975). The high water content in the setts is responsible for accelerating the conversion of carbohydrates into reducing sugars, resulting in higher germination percentage (Singh et al., 2008). Germination of water soaked setts improved by $75.9 \%$ over the control (Anonymous 2010). The present study was planned to see the effect of sett soaking with water or ethephon alone as well as in combination with foliar application of Gibberellic acid on productivity and juice quality of sugarcane.

\section{Materials and Methods}

A field experiment was conducted during spring 2015-2016 at the N.E. Borlaug Crop Research Centre of Govind Ballabh Pant University of Agriculture and Technology, Pantnagar (U.S. Nagar), Uttarakhand, India. The soil of the experiment plot was silty clay loam, rich in organic carbon (1.04\%), high in available phosphorus (32.5 $\left.\mathrm{kg} \mathrm{P}_{2} \mathrm{O}_{5} / \mathrm{ha}\right)$ and medium in available potassium $(256.2 \mathrm{~kg}$ $\mathrm{K}_{2} \mathrm{O} / \mathrm{ha}$ ). $\mathrm{pH}$ of the soil was 7.2. Ten treatments i.e. conventional planting $\left(\mathrm{T}_{1}\right)$, overnight soaking of setts in water $\left(\mathrm{T}_{2}\right)$, overnight soaking of setts in $50 \mathrm{ppm}$ ethephon $\left(\mathrm{T}_{3}\right)$, overnight soaking of setts in $100 \mathrm{ppm}$ ethephon $\left(\mathrm{T}_{4}\right), \mathrm{T}_{1}+$ foliar application of $\mathrm{GA}_{3}$ @ $35 \mathrm{ppm}$ at 90, 120 and $150 \operatorname{DAP}\left(\mathrm{T}_{5}\right), \mathrm{T}_{2}+$ 
foliar application of $\mathrm{GA}_{3} @ 35$ ppm at 90,120 and 150 DAP $\left(\mathrm{T}_{6}\right), \mathrm{T}_{3}+$ foliar application of $\mathrm{GA}_{3} @ 35 \mathrm{ppm}$ at 90,120 and 150 DAP $\left(\mathrm{T}_{7}\right)$, $\mathrm{T}_{4}+$ foliar application of $\mathrm{GA}_{3} @ 35 \mathrm{ppm}$ at 90, 120 and $150 \mathrm{DAP}\left(\mathrm{T}_{8}\right)$, soaking of setts for six hours in $50 \mathrm{ppm}$ ethephon $\left(\mathrm{T}_{9}\right)$ and six hour soaking of setts in $100 \mathrm{ppm}$ ethephon $\left(\mathrm{T}_{10}\right)$ were laid down in a randomized block design with three replications. Three budded sugarcane setts of variety Co pant-3220 were planted in flat bed method at a row to row spacing of $75 \mathrm{~cm}$. The crop was fertilized with $150 \mathrm{~kg} \mathrm{~N}, 60 \mathrm{~kg} \mathrm{P}_{2} \mathrm{O}_{5}$ and $40 \mathrm{~kg} \mathrm{~K} 2 \mathrm{O}$ and other cultural practices were followed as per recommendation.

Before planting setts were either soaked with water or ethephon. For water soaking treatment, setts were soaked overnight in tube well water. Setts were soaked in 50 and 100 ppm ethephon solution for two different duration i.e. 6 hours and overnight.

Ethephon treated setts were used for planting immediately after completion of soaking duration. Gibberellic acid was sprayed @ 35 ppm at 90, 120 and 150 days after planting. In conventional planting the setts were planted without any sett soaking treatment.

Data on cane yield and different quality parameters like juice extraction percentage, sucrose content (\%), available sugar (\%) and commercial cane sugar yield $(\mathrm{t} / \mathrm{ha})$ were calculated as follow.

For estimating juice extraction percent the sample of five canes after recording their fresh weight was crushed by electric motor driven roller crusher. Weight of juice was recorded and the juice extraction per cent was worked out as:

Juice extraction $(\%)=$ $\frac{\text { Weight of juice }(\mathrm{kg})}{\text { Weight of cane }(\mathrm{kg})} \times 100$
For estimation of sucrose content of cane, 100 $\mathrm{ml}$ of juice was taken in conical flask to which $1 \mathrm{~g}$ dry lead acetate was added followed by vigorous stirring. The impurities were filtered off by using Whatman No. 42 filter paper. The clear filtrate was taken in $20 \mathrm{~cm}$ polarimeter tube and pol reading was recorded with the help of polarimeter, using Hornal's Dry Lead Acetate method with dilute solution as described by Spencer and Meade (1955). Schmitz's table was used to calculate the sucrose per cent in juice by using corrected brix and pol reading.

Available sugar per cent in cane at harvesting was computed by using the following formula (Spencer and Meade, 1955).

Available sugar $(\%)$ in cane $=[\mathrm{S}-(\mathrm{B}-\mathrm{S}) \times$ $0.4] 0.73$

Where,

$\mathrm{S}=$ Sucrose per cent in cane juice

$\mathrm{B}=$ Corrected brix of cane juice

The yield of commercial cane sugar (CCS) at harvest was worked out as follows:

$\mathrm{CCS} \quad \begin{aligned} & \text { yield } \\ & \text { Available sugar }(\%) \text { in cane } \times \text { Cane y ield }(\mathrm{t} / \mathrm{ha})\end{aligned}$
100

\section{Results and Discussion}

\section{Cane yield}

The results clearly revealed that the productivity of sugarcane varies with different treatments. Highest cane yield (114.06 t/ha) was obtained from the treatment of overnight soaking of cane setts in $100 \mathrm{ppm}$ ethephon followed by three spraying of $\mathrm{GA}_{3} @ 35 \mathrm{ppm}$ at 90, 120 and 150 days after planting (Table 1). Corresponding cane yield in this treatment $\left(\mathrm{T}_{8}\right)$ was $67.85 \%$ higher than conventional method (no sett treatment). However the cane 
yield was increased in all the treatments over conventional, though the response was different in different treatments. It was also observed that $100 \mathrm{ppm}$ ethephon treated setts produced $9 \%$ higher cane over $50 \mathrm{ppm}$ when the duration of sett soaking was 6 hours. The response was more encouraging in $100 \mathrm{ppm}$ ethephon sett soaking over $50 \mathrm{ppm}$ for same duration of soaking.

The highest cane yield in the treatment of overnight sett soaking in $100 \mathrm{ppm}$ ethephon followed by $\mathrm{GA}_{3}$ spray $(35 \mathrm{ppm})$ at 90,120 and 150 days after planting was the cumulative effect of overnight sett soaking with $100 \mathrm{ppm}$ ethephon before planting and later on $\mathrm{GA}_{3}$ spray $(35 \mathrm{ppm})$ at 90,120 and 150 DAP. Soaking of setts with ethephon might have resulted the favorable physiobiochemical changes resulting in better germination. Higher germination in $\mathrm{T}_{8}$ helped in establishing a proper plant stand and helped in producing high yield. Higher germination in $\mathrm{T}_{8}$ was due to sett treatment with $100 \mathrm{ppm}$ ethephon. Jain et al., (2011) found that ethephon enhances acid invertase and ATPase activity which improves the availability of reducing sugar and energy respectively. Reducing sugar directly serves as food material for sprouting buds whereas inorganic phosphorus released by the activity of ATPase provides the cell with carbon and energy that helps for synthesizing compounds necessary for sprouting.

Number of shoots, height of shoots, leaf area index, shoot dry matter, root growth was also highest in the treatment in which setts were planted after overnight soaking with $100 \mathrm{ppm}$ ethephon followed by $\mathrm{GA}_{3}$ spraying @ 35 ppm at 90,120 and 150 DAP. Due to all these favourable growth parameters the yield was maximum in $\mathrm{T}_{8}$. Use of PGRs (ethephon and gibberellic acid) has been able to improve the productivity of sugarcane. Higher as well as faster germination along with higher tiller production due to ethephon treatment has been reported (Jain et al., 2011; Zhang et al., 2001). Foliar application of gibberellic acid has been found effective for improving productivity as well as juice quality. Bull (1964) reported that application of gibberellic acid increased stalk length, fresh weight and sugar content of sugarcane. Alexander (1968) also reported increase in yield and juice quality of sugarcane due to foliar application of gibberellic acid.

Even $28.18 \%$ increase in cane yield was reported in overnight soaking in water as compared to conventional. The yield improvement in water soaking treatment was due to better emergence and crop stand. When water soaked setts are planted, due to high moisture content the conversion of carbohydrates into reducing sugar is favoured. Glucose being a simplified form of sugar is quickly mobilized and utilized by the growing point of the sugarcane bud. Better sprouting ensured better crop stand, vigorous growth and thus produced high yield in this treatment.

\section{Quality parameters}

Data regarding quality parameters i.e. juice extraction percentage, sucrose percentage, available sugar and CCS (commercial cane sugar) yield has been given in Table 1 .

Juice extraction percentage was similar in all the treatments and statistically found nonsignificant. However other juice quality parameters like sucrose content, available sugar and commercial cane sugar yield improved significantly. The highest sucrose percentage was recorded in the treatment $T_{8}$ (overnight sett soaking in $100 \mathrm{ppm}$ ethephon + $\mathrm{GA}_{3} @ 35 \mathrm{ppm}$ applied at 90,120 and 150 DAP) which was significantly higher over rest of the treatments except the treatment $\mathrm{T}_{4}$ (overnight soaking of setts in $100 \mathrm{ppm}$ ethephon without $\mathrm{GA}_{3}$ spraying). 
Table.1 Yield and quality parameters of Sugarcane as influenced by various treatments

\begin{tabular}{|c|c|c|c|c|c|}
\hline Treatment & $\begin{array}{c}\text { Cane yield } \\
(\mathbf{t} / \mathbf{h a})\end{array}$ & $\begin{array}{c}\text { Juice } \\
\text { extraction } \\
(\mathbf{\%})\end{array}$ & Sucrose (\%) & $\begin{array}{c}\text { Available } \\
\text { sugar }(\mathbf{\%})\end{array}$ & $\begin{array}{c}\text { Commercial } \\
\text { cane sugar } \\
(\mathbf{t} / \mathbf{h a})\end{array}$ \\
\hline $\mathbf{T}_{\mathbf{1}}$ & 67.95 & 45.70 & 15.89 & 9.80 & 6.65 \\
\hline $\mathbf{T}_{\mathbf{2}}$ & 87.10 & 46.50 & 16.19 & 10.36 & 9.26 \\
\hline $\mathbf{T}_{\mathbf{3}}$ & 84.07 & 46.10 & 16.32 & 10.33 & 8.68 \\
\hline $\mathbf{T}_{\mathbf{4}}$ & 104.06 & 49.00 & 16.65 & 11.08 & 11.53 \\
\hline $\mathbf{T}_{\mathbf{5}}$ & 71.10 & 48.20 & 16.36 & 10.58 & 7.52 \\
\hline $\mathbf{T}_{\mathbf{6}}$ & 89.43 & 48.70 & 16.53 & 10.81 & 9.42 \\
\hline $\mathbf{T}_{\mathbf{7}}$ & 89.62 & 47.60 & 16.43 & 10.60 & 9.50 \\
\hline $\mathbf{T}_{\mathbf{8}}$ & 114.06 & 49.70 & 16.94 & 11.60 & 13.23 \\
\hline $\mathbf{T}_{\mathbf{9}}$ & 74.99 & 46.60 & 16.26 & 10.39 & 7.78 \\
\hline $\mathbf{T}_{\mathbf{1 0}}$ & 81.29 & 48.70 & 16.20 & 10.42 & 8.46 \\
\hline $\mathbf{C D}(\mathbf{P}=\mathbf{0 . 0 5})$ & 6.06 & $\mathrm{NS}$ & 0.31 & 0.4 & 0.82 \\
\hline
\end{tabular}

Lowest sucrose percentage (15.89) was recorded in conventional planting, where setts were planted without any sett treatment. The highest surose percent in ttreatment $\mathrm{T}_{8}$ can be attributed to better photosynthesis and sourcesink relation in the plant due to application of Gibberellic acid.

Significantly higher available sugar $(11.60 \%)$ was recorded in $\mathrm{T}_{8}$ over rest of the treatments. The lowest CCS (6.65 t/ha) was produced in conventional which was significantly lower than rest of the treatments. Significantly higher commercial cane sugar (13.23 t/ha) was produced in the treatment $T_{8}$ over rest of the treatments. Commercial cane sugar was almost doubled in $\mathrm{T}_{8}$ over conventional. Overnight soaking the setts in water, soaking setts for 6 hours in $50 \mathrm{ppm}$ ethephon also performed better over control. Improvement in commercial cane sugar due to foliar application of Gibberellic acid application was also observed by El-lattief and Bekheet (2012).

It can be concluded that overnight soaking of setts with $100 \mathrm{ppm}$ ethephon followed by foliar application of Gibberellic acid @ 35 ppm at 90, 120 and 150 DAP is useful for improving yield and juice quality parameters of sugarcane. The low cost technique like soaking of setts in water was also found to be useful in improving yield as well as quality. As this production technology improves cane yield with simultaneous increase in sucrose content and commercial cane sugar yield, hence sugar industry will also be benefitted.

\section{References}

Alexander, A.G. 1968. Interrelationship of GA and nitrate in sugar production and enzyme activity of sugarcane. Journal of Agric. Univ. of Puerto Rico. 52(1): 19-28.

Anonymous, 2010. Annual report 2009-2010. Indian institute of sugarcane research, Lucknow. pp. 19-20.

Anonymous. 2011. Vision 2030. Indian institute of sugarcane research, Lucknow. pp. 1-4.

Bull, T.A. 1964. The effects of temperature, variety and age on the response of Saccharum spp. to applied gibberellic acid. Austrian Journal of Agricultural Research. 15: 77-84. 
El-Lattief, E.A.A. and M.A. Bekheet, 2012. Quantitative and qualitative attributes of three sugarcane varieties as influenced by foliar spray of some growth regulators under upper Egypt conditions. Sugar Tech. 14(4):345-350

Jain, R., A.K. Shrivastava, S. Solomon, and R.L. Yadav. 2007. Low temperature stress-induced biochemical changes in stubble bud sprouting in sugarcane (Saccharum sp. hybrid). Plant Growth Regulation. 53: 17-23

Li, Y. and S. Solomon. 2003. Ethephon: a versatile growth regulator for sugarcane industry. Sugar Tech. 5(4): 213-223.ne

Manoharan, M.L., C. Ramaswani and M.S.T.I. Ramakrishnan. 1992. Management of sugarcane under moisture stress conditions. Madras Agric. J. 79: 460-464.

Millhollon, R.W. \& B.L. Legendre. 1995. Influence of ethephon on plant population and yield of sugarcane (Saccharum spp. hybrids). Plant Growth Reg. Soc. Am. Quarterly 23: 1730.

Rao, M.S., M. Krishnamurthy, and P. Weerathaworn. 2005. Beneficial effect of Ethephon on yield and sucrose productivity of sugarcane cultivars in
Thailand. Sugar technology. 7(2\&3): 48-52

Singh, A.K., M. Lal, I. Singh, R.L. Yadav, and D.V. Yadav. 2008. Effect of planting method and drought management technique on growth, yield and quality of sugarcane (Saccharum hybrid complex) under limited irrigation. Indian Journal of Agronomy, 53(3): 200-204.

Singh, S. 1975. Significance of critical nodal water content of sugarcane sett on germination of buds. Science and Culture. 41: 475-477.

Spencer, G.L. and Meade, G.P. 1955. Cane sugar handbook- A manual for cane sugar manufacturers and their chemist. John Willey and Sons Inc. N.Y. Chapman and Hall Ltd., London.

Verma, H.P. and S. Sudama. 1965. Studies in cane sett germination under varying soil moisture status. Indian Sugarcane Journal. 9: 157-160.

Zhang, X.J., Y.R. Li, and Y.K. Lin. 2001. Effects of different concentration of Ethephon soaking seed cane on agronomical characters and some physiological and biochemical characters in sugarcane stalk tissue. Sugarcane. 8(3): 14-19.

\section{How to cite this article:}

Subhashisa Praharaj, Dheer Singh and Guru, S.K. 2018. Yield and Juice Quality of Sugarcane As Influenced By Ethephon and Gibberellic Acid. Int.J.Curr.Microbiol.App.Sci. 7(11): 16471652. doi: https://doi.org/10.20546/ijcmas.2018.711.187 